(p-ISSN: 1412-6095|e-Issn: 2407-1587

Vol. 19, No. 2, 2020, Hal. 121 - 130

\title{
PERBEDAAN TINGKAT KEBERSYUKURAN PADA PEREMPUAN LAJANG DAN SUDAH MENIKAH
}

\author{
Rosadi \\ Universitas Islam Negeri Sunan Kalijaga Yogyakarta, Indonesia \\ rosadif95@gmail.com
}

\begin{abstract}
The sense of gratitude that women have is not always the same between single and married women. Subjects in this study were 46 participants aged 22-36 years. The instrument used in this study was the GQ-6 gratitude scale compiled by McCullough, Emmons \& Tsang. The data analysis used was the 2-sample difference test technique, namely the Independent sample t-test. Based on the results of the research data analysis, it can be concluded that there are significant differences in single and married women related to the level of gratitude. This can be seen from the results of statistical data analysis with the t test technique which shows a probability value of $0.034>0.05$ which indicates a significant difference. Thus the difference in the average actually occurs in real terms. In conclusion, married women have a bigher level of gratitude $(M=35.95)$ than single women $(M=34.04)$.
\end{abstract}

Keywords: Gratefulness, Married Women, Single Women

\begin{abstract}
ABSTRAK
Rasa kebersyukuran yang dimiliki oleh perempuan tidak selalu sama antara perempuan lajang dan menikah. Subjek dalam penelitian ini berjumlah 46 orang partisipan yang berumur 22-36 tahun. Instrumen yang digunakan dalam penelitian ini adalah skala syukur GQ-6 yang di susun oleh McCullough, Emmons \& Tsang. Analisis data yang digunakan adalah teknik uji perbedaan 2 sampel yaitu Independent sampel t-test. Berdasarkan hasil analisis data penelitian dapat diperoleh kesimpulan bahwa terdapat perbedaan yang signifikan pada perempuan lajang dan sudah menikah terkait dengan tingkat kebersyukuran. Hal tersebut dapat dilihat dari hasil analisis data statistik dengan teknik uji t yang menunjukkan nilai probabilitas 0,034>0,05 yang mengindikasikan adanya perbedaan yang signifikan. Dengan demikian perbedaan rata-rata yang ada benar-benar terjadi secara nyata. Sebagai kesimpulannya adalah perempuan yang sudah menikah memiliki tingkat kebersyukuran yang lebih tinggi $(M=35,95)$ dibandingkan perempuan lajang $(M=34,04)$.
\end{abstract}

Kata Kunci: Kebersyukuran, Perempuan Lajang, Perempuan Sudah Menikah 


\section{PENDAHULUAN}

Pada dasarnya seorang perempuan merupakan sosok pendamping bagi seorang laki-laki, yang mana mereka telah di takdirkan untuk berpasang-pasang sebagaimana tercantum dalam kitab suci Al-Quran, bahkan dalam sejarah para nabi pun perempuan menjadi sosok yang sangat berpengaruh sebagai mana dalam kisah Nabi Adam bahwa Hawa adalah perempuan pertama yang diciptakan dari tulang rusuk Adam. Tidak hanya itu hawa pun sangat berperan dalam proses berkembangnya manusia yang ada di seluruh dunia.

Perkembangan pada masa dewasa ini, seorang perempuan tentunya memiliki sebuah permasalahan yang mesti dihadapi dalam kehidupannya. Permasalahan tersebut dinilai mempunyai efek yang mampu mengurangi stabilitas kesehatan baik fisik maupun mental seseorang. Tekanan demi tekanan yang dialami akan membuat seseorang merasa berada pada posisi terendahnya baik di kehidupan sosial maupun di hadapan Sang Pencipta. Mengingat ada beberapa perempuan yang rentan akan stres yang akhirnya mengakibatkan depresi, kemungkinan disebabkan oleh kurangnya rasa bersyukur yang dimiliki oleh setiap orang, khususnya bagi seorang perempuan baik itu dengan status lajang maupun sudah menikah. Dari status tersebut sebagian kecil akan berdampak pada perbedaan tingkat kebersyukuran pada perempuan.

Rasa bersyukur yang dilakukan oleh seseorang dengan mengakui bahwa kebermaknaan hidup itu sangat penting, sehingga menjadi prediktor sebuah kebahagiaan. Rasa bersyukur tersebut menjadikan diri seseorang memiliki pandangan positif terhadap kehidupan kemudian muncul keinginan untuk meningkatkan serta mempertahankannya (Froh dkk., 2009). Menurut Marettih \& Wahdani (2017) rasa bersyukur bisa diperoleh salah satunya melalui pertemuan dengan orang lain yang mengalami kondisi lebih sulit. Hal ini terbukti dari penelitian mereka tentang rasa bersyukur bagi orang tua yang memiliki anak autis. Anak autis setidaknya memiliki fisik yang sempurna sehingga sehari-hari mereka masih dapat melakukan aktivitasnya secara mandiri.

Syukur diartikan sebagai penghadiran akan ingatan atas apa yang telah Allah berikan berupa nikmat, baik nikmat lahir maupun nikmat batin. (Tazaka, 2014). Rasa syukur merupakan bentuk ungkapan terima kasih atas nikmat yang diberikan oleh Allah SWT (Kusumastuti dkk., 2017) dan menerima ketetapan Allah baik yang menyenangkan maupun sebaliknya (Haryanto \& Kertamuda, 2016) dan menikmati hidup dari melihat hal-hal positif dalam proses kehidupan yang dijalaninya (Emmons, \& Mishra, 2012) dan menghargai diri sendiri demi mencapai tujuan yang positif sebagai upaya mengubah diri dari dalam serta memiliki pandangan hidup bahwa masih ada Tuhan yang mengatur kehidupan (Rahmalia, 2018).

Kebersyukuran mampu menyediakan kepuasan hidup dengan menempuh jalur untuk meningkatkan integrasi sosial (Froh dkk., 2010), serta mampu memperkuat kepuasan hidup 
Vol. 19, No. 2, 2020, Hal. 121 - 130

dengan selalu melakukan hal yang baik sebagai panutannya. Dengan bersyukur kekuatan hati mampu mendorong ikatan emosi di antara setiap orang yang memiliki hal-hal yang baik (Peterson, 2013).

Rasa syukur berperan atas kesejahteraan fisik, kesejahteraan psikologis, dukungan sosial, teman sebaya, lingkungan sekolah, hubungan orang tua, kemandirian (Wijayanti dkk., 2018) serta memunculkan emosi positif dan self-esteem di dalam kehidupan sehari-hari (Kashdan dkk., 2006) kemudian menghasilkan kebiasaan yang menjadikan seseorang lebih merasa diterima, dihargai serta dicintai oleh orang lain (Emmons dkk., 2003). Nilai-nilai kebersyukuran ditunjukkan dengan mengakui bahwa segala hal yang di dapat hanya dari Tuhan Semata (Maulidah, 2016).

Rasa syukur mampu mengubah seseorang menjadi lebih baik, menjadi lebih bijaksana dalam menghadapi segala aspek permasalahan, serta mampu menjadikan harmonis mantra kehidupan sendiri dengan lingkungan dan komunitas (Emmons, 2008). Bentuk dari syukur dibagi menjadi tiga, syukur hati dalam pengertian mengingat nikmat yang telah Allah berikan mencakup nikmat lahir maupun batin, nampak maupun tidak nampak, iman, nafas, nyawa, darah dan seluruh orang yang dimiliki setiap makhluk. Syukur dengan lisan yaitu mengucapkan pujian atas nikmat yang diterima. Syukur anggota badan yaitu membalas nikmat sesuai kewajiban masing-masing anggota badan yang dimiliki setiap makhluk (Tazaka, 2014).

Dalam penelitian Mc.Cullough dkk (2004) mengemukakan bahwasannya salah satu faktor yang mempengaruhi rasa bersyukur adalah religiusitas (McCullough dkk., 2004). Religiusitas biasanya diartikan sebagai nilai-nilai dari sebuah keberagamaan. Agama dilandasi dengan spiritual memiliki banyak sumber daya baik kognitif maupun sosial yang serta merta mampu mempercayai akan adanya kesejahteraan yang lebih luas. Nilai-nilai keagamaan yang dipahami oleh seseorang memiliki dampak yang sangat besar dalam suatu kebersyukuran (Kristanto, 2016).

Al-Gahazali (Al-Bantanie, 2009), menjelaskan bahwa bersyukur terdiri dari tiga perkara, yaitu:

a. Mempunyai pengetahuan tentang nikmat, artinya bahwa segala nikmat yang diterima, serta kebaikan adalah berasal dari Allah dan Allah-lah yang memberikan kepada pengetahuan tersebut kepada orang-orang yang dikehendaki-Nya

b. Memiliki sikap jiwa yang tetap dan tidak berubah, sehingga hasil dari pengetahuan yang telah dimiliki tersebut menjadikannya selalu merasa senang, kemudian mencintai yang telah memberikan nikmat tersebut dengan bentuk kepatuhan kepada Allah

c. Menghindarkan diri dari perbuatan maksiat yang telah dilarang oleh Allah 
Vol. 19, No. 2, 2020, Hal. 121 - 130

McCullough dkk (2002) menyatakan bahwa ada beberapa faktor yang mempengaruhi Gratitude yaitu:

a. Emotionality yaitu suatu kecenderungan di mana seseorang merasa emosional dan menilai kepuasan hidupnya.

b. Prosociality yaitu kecenderungan seseorang untuk diterima di lingkungan sosial.

c. Religiousness yaitu sesuatu yang berkaitan dengan nilai-nilai transendental, keagamaan dan keimanan seseorang.

Sedangkan menurut Kashdan dkk., (2009) faktor-faktor yang mempengaruhi gratitude yaitu:

a. Afek positif yakni perasaan positif individu yang dapat menimbulkan gratitude

b. Persepsi teman sebaya yang memberikan pengaruh kepada individu untuk bersyukur.

c. Peran keluarga dalam memberikan dukungan terhadap individu ketika menghadapi permasalahan sehingga individu akan merasa lebih bersyukur karena adanya dukungan dan perhatian yang diterima.

d. Rasa optimis yang menjadikan individu cenderung menilai segala sesuatu secara positif.

Menurut McCullough dkk., (2002) mengungkapkan aspek-aspek bersyukur terdiri dari empat unsur, yaitu:

a. Intensity, seseorang yang bersyukur ketika mengalami peristiwa positif diharapkan untuk merasa lebih intens bersyukur.

b. Frequency, seseorang yang memiliki kecenderungan bersyukur akan merasakan banyak perasaan bersyukur setiap harinya dan syukur bisa menimbulkan dan mendukung tindakan dan kebaikan sederhana atau kesopanan.

c. Span, maksudnya adalah dari peristiwa-peristiwa kehidupan ia membuat seseorang merasa bersyukur, misalnya merasa bersyukur atas keluarga, pekerjaan, kesehatan, dll.

d. Desity, maksudnya adalah orang yang bersyukur diharapkan dapat menuliskan lebih banyak nama-nama orang yang dianggap telah membuatnya bersyukur, termasuk orang tua, teman, keluarga, dll.

Permasalahan yang muncul dalam penelitian ini, yakni apakah ada perbedaan pada seorang perempuan baik yang belum menikah ataupun sudah menikah dalam perihal kebersyukuran yang dimiliki oleh perempuan. Tujuan dari penelitian ini adalah untuk melihat tingkat perbedaan dari kebersyukuran pada perempuan lajang dan perempuan yang sudah menikah. Adapun dalam penelitian ini akan menjabarkan mengenai konsep dari rasa kebersyukuran serta faktor apa saja yang mempengaruhi pada kebersyukuran. 


\section{METODE PENELITIAN}

Penelitian ini menggunakan mode penelitian dengan pendekatan secara kuantitatif dan jenis penelitiannya adalah bersifat komparatif, metode ini digunakan dalam menjelaskan perbandingan atau perbedaan antara variabel-variabel yang terdapat dalam penelitian (Sugiyono, 2007). Peneliti mengambil populasi yaitu dari perempuan lajang dan perempuan yang sudah menikah. Teknik pengambilan sampel yang digunakan dalam penelitian ini adalah Convenience Sampling dengan tujuan populasi yang terlalu banyak sehingga tidak memungkinkan dilakukannya pengambilan data kepada seluruh populasi, terdapat keterbatasan baik dalam tenaga, waktu serta biaya, dan adanya asumsi bahwa seluruh populasi seragam sehingga bisa diwakili oleh sampel.Dengan jumlah partisipan sebanyak 46 orang yang terdiri dari 23 orang perempuan lajang dan 23 orang perempuan sudah menikah yang memiliki rentang lumut 22 - 36 tahun.

Instrumen penelitian yang digunakan dalam penelitian ini adalah kuesioner yang sudah disusun oleh McCullough dkk., (2004) mengenai perihal mengukur tingkat kebersyukuran yang biasa disebut dengan Gratitude Questionare $\left(G Q^{-6}\right)$. Pada penelitian ini setiap jawaban pada item pertanyaan kuesioner menggunakan skala interval, yakni skala yang memiliki gradasi jawaban mulai dari sangat positif sampai dengan negatif yang diangkakan dengan skor 1 sampai dengan 7 .

\section{Tabel 1. Klasifikasi Skoring}

\begin{tabular}{|c|c|}
\hline Klasifikasi Skoring & Skor \\
\hline Sangat Setuju & 7 \\
\hline Setuju & 6 \\
\hline Sedikit Setuju & 5 \\
\hline Netral & 4 \\
\hline Sedikit Tidak Setuju & 3 \\
\hline Tidak Setuju & 2 \\
\hline Sangat Tidak Setuju & 1 \\
\hline
\end{tabular}

Adapun dasar pengambilan keputusan dalam uji Independent sample t-Test sebagai berikut,

1. Jika nilai Sig. (2-tailed) $>0,05$ maka $\mathrm{H}_{0}$ diterima dan $\mathrm{H}_{\mathrm{a}}$ ditolak, yang berarti tidak ada perbedaan tingkat kebersyukuran antara perempuan lajang dengan perempuan sudah menikah. 
Vol. 19, No. 2, 2020, Hal. 121 - 130

2. Jika nilai Sig. (2-tailed) $<0,05$ maka $\mathrm{H}_{0}$ ditolak dan $\mathrm{H}_{\mathrm{a}}$ diterima, yang berarti ada perbedaan tingkat kebersyukuran antara perempuan lajang dengan perempuan sudah menikah.

Adapun hipotesis yang diajukan dalam penelitian ini adalah:

$\mathrm{H}_{0}=$ Tidak ada perbedaan tingkat kebersyukuran antara perempuan lajang dengan perempuan sudah menikah.

$\mathrm{H}_{\mathrm{a}}=$ Ada perbedaan tingkat kebersyukuran antara perempuan lajang dengan perempuan sudah menikah.

Analisis yang digunakan untuk penelitian adalah statistik uji hipotesis komparatif (Uji-t), yaitu Independent Sampel t-test. Data yang di analisis menggunakan uji independen sampel t-test dikarenakan penelitian ini bertujuan untuk menguji mengenai perbedaan dua sampel data independen yaitu tingkat kebersyukuran pada perempuan lajang dan perempuan sudah menikah.

\section{HASIL DAN PEMBAHASAN}

Hasil penelitian ini dapat dilihat sebagaimana tertera pada Tabel 2.

Tabel 2. Group Statistic

\begin{tabular}{|c|c|c|c|c|c|}
\hline & & & & Std. & Std. Error \\
\hline & Perempuan & $\mathrm{N}$ & Mean & Deviation & Mean \\
\hline \multirow[t]{4}{*}{ Hasil } & Perempuan Lajang & 23 & 34,04 & 3,2680 & ,6814 \\
\hline & & & 3 & & \\
\hline & Perempuan Sudah & 23 & 35,95 & 2,6021 &, 5426 \\
\hline & Menikah & & 7 & & \\
\hline
\end{tabular}

Berdasarkan tabel output "Group Statistics" di atas diketahui jumlah data tingkat kebersyukuran untuk perempuan lajang adalah sebanyak 23 orang, sementara untuk perempuan sudah menikah adalah sebanyak 23 orang. Nilai rata-rata atau mean untuk perempuan lajang adalah sebesar 34,043, sementara untuk perempuan sudah menikah adalah sebesar 35,957. Dengan demikian secara deskriptif statistik dapat di simpulkan ada perbedaan rata-rata tingkat kebersyukuran antara perempuan lajang dan perempuan sudah menikah.

Adapun dalam membuktikan apakah perbedaan tersebut berarti signifikan (nyata) atau tidak maka perlu adanya pengujian, dalam hal ini pengujian yang digunakan yakni dengan output "Independent Sampels Test". 


\section{Tabel 3. Independent Samples Test}

Levene's

Test for

Equality of

t-test for Equality of Means

Variances

F Sig. $\mathrm{t}$ df $\begin{gathered}\text { Sig. (2- } \\ \text { tailed) } \\ \end{gathered}$

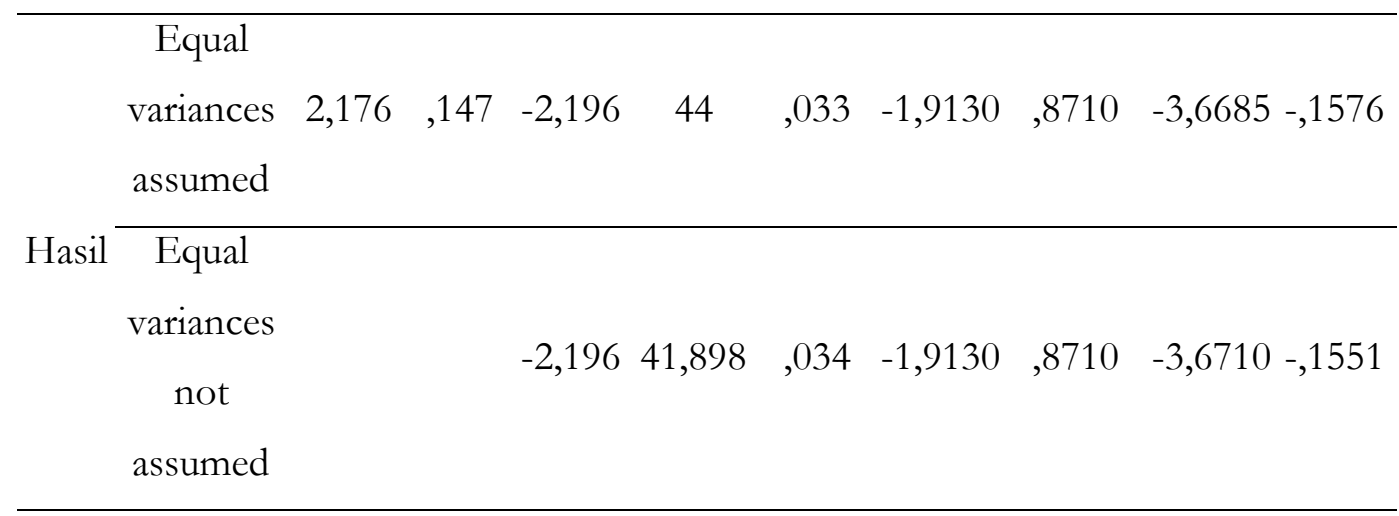

Berdasarkan output di atas diketahui nilai Sig. Levene's Test for Equality of Variances adalah sebesar 0,147>0,05 maka dapat di artikan bahwa varian data antara perempuan lajang dan perempuan sudah menikah adalah homogen atau sama (Sujarweni, 2014). Sehingga penjabaran pada tabel output Independent Samples Test di atas berpedoman pada nilai yang terdapat dalam tabel "Equal variances assumed" diketahui nilai Sig. (2-tailed) sebesar 0,033<0,05, maka sebagaimana dasar pengambilan keputusan dalam uji Independent sample $t$ Test dapat disimpulkan bahwa $\mathrm{H}_{0}$ ditolak dan $\mathrm{H}_{\mathrm{a}}$ diterima. Dengan demikian dapat disimpulkan bahwa ada perbedaan yang signifikan (nyata) antara rata-rata tingkat kebersyukuran pada perempuan lajang dengan perempuan sudah menikah.

Hal tersebut sejalan dengan temuan dari penelitian yang menunjukkan bahwa dengan menjalani pernikahan, seseorang akan semakin bersyukur sebagaimana mata rantai paling kuat yang memiliki hubungan dengan kesehatan mental seseorang, serta bisa lebih kuat daripada dengan sifat positif lainnya, seperti harapan atau pun optimis Khairani dkk., (2016). Kebersyukuran yang tinggi cenderung akan memberikan efek positif pada seseorang serta mampu menenangkan batin, menjadikan cara pandang menjadi positif, dan mampu memberikan motivasi hidup yang kuat termasuk pada sebuah permasalahan mengenai pernikahan yang mampu 
Vol. 19, No. 2, 2020, Hal. 121 - 130 diselesaikan dengan baik serta mendapat pengaruh kepuasan yang tinggi dalam pernikahan (Julike dkk., 2019). Pengekspresian rasa syukur mampu memicu kepercayaan pada pasangan, bahkan tatkala kebersyukuran tersebut dirasakan lebih mendalam maka kenyamanan akan tercipta dalam sebuah hubungan Khairani dkk., (2016). Rasa syukur juga mampu meningkatkan hormon kebahagiaan serta keintiman yang tentunya menghasilkan kepuasan pernikahan yang lebih baik (Gordon dkk., 2011).

Rasa bersyukur memiliki kekuatan magis dalam sisi mendukung terjadinya sebuah hubungan. Tidak menutup kemungkinan bahwa rasa syukur mampu memprediksi peningkatan sebuah relasi serta kepuasan suatu hubungan di kemudian hari, baik sebagai pemberi ataupun penerima kebaikan. Dalam bersyukur hakikatnya memiliki keterkaitan dengan kualitas hubungan jangka panjang semisal hubungan romantis dalam perihal hubungan pernikahan yang memiliki ciri bahwa setiap orang memberikan keuntungan satu sama lain (Khairani dkk., 2016).

Menurut beberapa studi yang dijabarkan, bahwa perempuan yang sudah menikah disertai kualitas pernikahan yang baik tidak akan mengalami stres yang berat melainkan turunnya tingkat stres secara psikologis menjadi rendah dikarenakan memiliki banyak keuntungan dalam sebuah pernikahan, semisal dukungan emosional, dukungan sosial serta dukungan ekonomi, yang memungkinkan memiliki tingkat depresi lebih rendah dibandingkan perempuan lajang (Christie dkk., 2013). Keberadaan perempuan lajang merupakan suatu masa yang bersifat temporary (sementara) atau jangka pendek yang berfokus untuk hidup mandiri secara finansial (Rahmalia, 2018), serta adanya dukungan sosial yang dirasakan terkait menikmati dan bahagia dengan kehidupan melajang (Christie dkk., 2013).

Dalam sebuah penelitian dikatakan bahwa perempuan lajang yang memiliki rentang usia antara 35-65 tahun merasa lebih tertekan, tidak puas, tidak tercukupi, depresi, stres, tidak bahagia dan tidak sehat secara emosi dibandingkan dengan perempuan sudah menikah yang memiliki pernikahan dengan kualitas baik, relasi yang sehat antara suami, serta pernikahan yang bahagia (Christie dkk., 2013).

\section{PENUTUP}

Berdasarkan hasil penelitian dapat diperoleh kesimpulan bahwa terdapat perbedaan yang signifikan pada perempuan lajang dan sudah menikah mengenai tingkat kebersyukuran. Hal tersebut dapat dilihat dari hasil analisis data dengan teknik uji-t yang menunjukkan nilai probabilitas 0,034>0,05 yang berarti terdapat perbedaan yang signifikan. Dengan demikian perbedaan Mean yang ada benar-benar terjadi secara nyata. Sebagai kesimpulannya adalah 
Vol. 19, No. 2, 2020, Hal. 121 - 130 perempuan yang sudah menikah memiliki tingkat kebersyukuran yang lebih tinggi $(\mathrm{M}=35,95)$ dibandingkan perempuan lajang $(\mathrm{M}=34,04)$.

\section{DAFTAR PUSTAKA}

Abu Rizki Tazaka. (2014). Energi Syukur, istigfar, muhasabah (tiga pintu kearifan). Al-Kamil.

Al-Bantanie, S. (2009). Dabsyatnya syukur. Qultum Media.

Rahmalia, D. (2018). Makna Hidup Pada Wanita Dewasa Madya Yang Belum Menikah. Kognisi Jurnal, 3(1), 23-32.

Emmons, R. A. (2008). Gratitude, subjective well-being, and the brain. Dalam The science of subjective well-being (hlm. 469-489). Guilford Press.

Emmons, R. A., \& Mishra, A. (2012). Why gratitude enhances well-being: What we know, what we need to know. Oxford University Press.

Emmons, R. A., McCullough, M. E., \& Tsang, J.-A. (2003). The assessment of gratitude. Dalam Positive psychological assessment: A handbook of models and measures (hlm. 327-341). American Psychological Association. https://doi.org/10.1037/10612-021

Froh, J. J., Bono, G., \& Emmons, R. (2010). Being grateful is beyond good manners: Gratitude and motivation to contribute to society among early adolescents. Motivation and Emotion, 34(2), 144-157. https://doi.org/10.1007/s11031-010-9163-z

Froh, J.J., Yurkewicz, C., \& Kashdan, T.B. (2009). Gratitude and subjective well-being in early adolescence: Examining gender differences. Journal of Adolescence, 32(3), 633-650. https://doi.org/10.1016/j.adolescence. 2008.06.006

Gordon, C., Arnette, R., \& Smith, R. (2011). Have you thanked your spouse today?: Felt and expressed gratitude among married couples. Personality and Individual Differences, 50, 339_ 343. https://doi.org/10.1016/j.paid.2010.10.012

Haryanto,H.C. \& Kertamuda, F.E. (2016). Syukur Sebagai Sebuah Pemaknaan. InSight, 18(2), 109_ 118.

Julike, Sarinah, \& Sri Hartini. (2019). Hubungan antara Gratitude dengan Kepuasan Perkawinan Pada Pasangan Menikah di KOmplek Merbau Mas Medan. InSight, 15(1). https://doi.org/10.32528/ins.v15i1.1618

Kashdan, T. B., Mishra, A., Breen, W. E., \& Froh, J. J. (2009). Gender Differences in Gratitude: Examining Appraisals, Narratives, the Willingness to Express Emotions, and Changes in Psychological Needs. Journal of Personality, 77(3), 691-730. https://doi.org/10.1111/j.14676494.2009.00562.x 
Vol. 19, No. 2, 2020, Hal. 121 - 130

Kashdan, T., Uswatte, G., \& Julian, T. (2006). Gratitude and hedonic and eudaimonic well-being in Vietnam War veterans. Behaviour research and therapy, 44, 177-199. https://doi.org/10.1016/j.brat.2005.01.005

Kristanto, E. (2016). Perbedaan Tingkat Kebersyukuaran pada Laki-laki dan Perempuan. 7.

Maulidah, I. L. (2016). Kebersyukuran dan Kebermaknaan Hidup pada Penderita Jantung Koroner. Psycho Idea, 14(2), 10-16-16. https://doi.org/10.30595/psychoidea.v14i2.2116

Khairani, M., Rachmatan, R., Sari, K., Sulistyani, A., \& Soraiya. P. (2016). Kebersyukuran dan Kepuasan dalam Pernikahan: Sebuah Tinjauan Psikologis pada Wanita Dewasa Muda. Gender Equality: International Journal of Child and Gender Studies, 2(1), 77-87.

Marettih, A.K.E., \& Wahdani, S.R. (2017). Melatih kesabaran dan wujud rasa syukur sebagai makna coping bagi orang tua yang memiliki anak autis, Marwah: Jurnal Perempuan, Agama, dan Gender, 16 (1), 13-31.

McCullough, M. E., Emmons, R. A., \& Tsang, J.-A. (2002). The grateful disposition: A conceptual and empirical topography. Journal of Personality and Social Psychology, 82(1), 112-127. https://doi.org/10.1037/0022-3514.82.1.112

McCullough, M. E., Tsang, J.-A., \& Emmons, R. A. (2004). Gratitude in Intermediate Affective Terrain: Links of Grateful Moods to Individual Differences and Daily Emotional Experience. Journal of Personality and Social Psychology, 86(2), 295-309. https://doi.org/10.1037/0022-3514.86.2.295

Peterson, J. (2013). Three Forms of Meaning and the Management of Complexity.

Sugiyono. (2007). Metode Penelitian Kuantitatif Kualitatif dan R\&D. Alfabeta.

Sujarweni, V. W. (2014). SPSS untuk Penelitian / V. Wiratna Sujarweni; editor, Florent (Ed.1 Cet. 1). Pustaka Baru Press.

Kusumastuti, W., Setyorini, N., \& Laksono, R.A. (2017). Makna Kebersyukuran Berdasarkan Kajian Psikologis dan Kajian Tafsir Al Misbah. SEMNASBAHTERA.

Wijayanti, S., Listiyandini, R. A., \& Rahmatika, R. (2018). Peran Kebersyukuran terbadap Kualitas Hidup Kesehatan pada Remaja di Panti Asuhan [Text]. Peran Kebersyukuran terhadap Kualitas Hidup Kesehatan pada Remaja di Panti Asuhan. https://doi.org/10.13140/rg.2.2.32145.07527

Christie, Y., Hartanti, H., \& Nanik, N. (2013). Perbedaan Kesejahteraan Psikologi pada Wanita Lajang Ditinjau dari Tipe Wanita Lajang. Calyptra: Jurnal Ilmiah Mabasiswa Universitas Surabaya, 2(1). 